\title{
Geotechnical Engineering Properties of Peat, Stabilized with a Combination of Fly Ash and Well Graded Sand
}

\author{
S.Venuja, S. Mathiluxsan and M.C.M. Nasvi
}

\begin{abstract}
Peat has several unfavourable characteristics such as low bearing capacity, high compressibility, high content of natural water and difficulty of access and thus is not suitable for Civil Engineering constructions. One of the widely used techniques for its improvement is its chemical stabilization through the addition of chemical admixtures such as ordinary Portland cement, lime, fly ash, natural fillers etc. This research was focused on stabilizing peat using low Ca fly ash (ASTM Class F) combined with well graded sand. An experimentally based approach was followed to analyse the stabilization of peat samples with different proportions of fly ash (10,20 and $30 \%$ by weight) and 125 $\mathrm{kg} / \mathrm{m}^{3}$ of well graded sand. With the increase in the fly ash content, the Maximum Dry Density (MDD) increased while the Optimum Moisture Content (OMC) decreased. The Unconfined Compressive Strength (UCS) increased with the addition of fly ash up to $10 \%$ by weight and thereafter it began to reduce as more and more fly ash was added. The UCS increase with curing period for all of the stabilized samples. Rowe cell test results showed that there was an improvement in the compressibility of peat after stabilization. On the whole, it was found that the geotechnical engineering properties of peat can be improved by stabilizing it using fly ash and well graded sand.
\end{abstract}

Keywords: Chemical stabilization, Fly ash, Peat, Rowe cell, Unconfined compressive strength

\section{Introduction}

Peat is an accumulation of partially decomposed and disintegrated plant remains under conditions of incomplete aeration and high water content. Peat lands cover nearly 400 million ha of earth in the world and in Sri Lanka alone there are 25000 ha of peat lands [1]. It has unfavourable characteristics such as low bearing capacity, low specific gravity, medium to low permeability, high compressibility, high content of natural water, high water holding capacity, high rates of creep and difficult accessibility [2, 3]. Based on its fibre content peat is classified mainly into two categories: fibrous peat and amorphous peat. Fibrous peat is dark brown or black in colour and has quite larger particles. Amorphous peat has smaller organic grains. It has a lower void ratio, a lower permeability and a lower compressibility than fibrous peat. When fibre content is higher than $20 \%$, it is known as fibrous peat and vice versa for amorphous peat [4]. In the Von Post scale system, peat is classified based on its degree of humification, water content, fibre content and botanical composition with a range extending from $\mathrm{H} 1$ to $\mathrm{H} 10$. $\mathrm{H} 1$ is completely fibrous peat and H10 is completely amorphous peat [5].

Engineers face many problems when they use peat lands for their construction work. The major problems are instability, slip failure, localized sinking and long term settlement [3, 5, 6]. There is a need for more land area for construction because of the increase in population. Therefore, it is necessary to improve peat lands so that they can be used for construction. There are two main common types of improvement techniques used in the stabilization of peat:- (i) mechanical method, and (ii) chemical method. The mechanical method of stabilization includes displacement and replacement, stage construction, pre loading, stone columns, piles, vertical drains and light weight fill $[3,5,6]$. In the chemical method, deep in-situ mixing and surface stabilization are used by adding chemical admixtures such as sand, cement, fly ash, gypsum, bentonite, sodium chloride etc., to peat $[1,7]$. Generally, lime and cement are used in deep mixing. Dry Mixing Method (DMM), Dry Jet Mixing (DJM) and Wet Mixing Method (WMM) are the different types of deep mixing methods used [5].

This research focused on using chemical stabilization for improving peat using a combination of fly ash and well graded sand as stabilizers. There are many studies [1 - 12] that have focused on the stabilization behaviour of peat. The sections below summarize the findings of those previous studies.

Miss. S.Venuja B.Sc. Eng. (Hons)(Peradeniya),
Department of Civil Engineering, University of
Peradeniya. Email:venusarma92@gmail.com
Mr. S.Mathiluxsan B.Sc. Eng. (Hons)(Peradeniya),
Department of Civil Engineering, University of
Peradeniya. Email:smlunsan7@gmail.com
Eng. (Dr.) M.C.M.Nasvi, AMIE(Sri Lanka), B.Sc. Eng.
(Hons) (Peradeniya), Ph.D. (Monash), Senior Lecturer of
Civil Engineering, Department of Civil Engineering,
University of Peradeniya. Email:nasvimcm@pdn.ac.lk


A detailed study was carried out by Youventharan et al [11] to investigate the effect of the amount of fibre content and organic content on the compressibility behaviour of peat. Rowe cell method and odeometer method have been used to obtain the compressibility parameters. From the outcomes, it was noted that the compression index $\left(\mathrm{C}_{c}\right)$ and the coefficient of secondary compression $\left(\mathrm{C}_{\mathrm{a}}\right)$ obtained from the Rowe cell were higher than those obtained from the odeometer for given peat and stress conditions. This is because there is no induction of back pressure and no measurement of pore water pressure in the odeometer test. Fibric peat had higher settlements than hemic and sapric peats, because of the higher fibre content in fibric peat.

Youventharan et al [12] suggested several methods of utilizing peat land for housing schemes. They cited uncontrolled land filling and groundwater lowering due to overdrainage as the reasons for land subsidence on peat. The construction methods recommended for peat are displacement and replacement, deep stabilization method, preloading and vertical drains which will minimize post construction settlement, and light weight foundation systems.

Bujang et al [5] presented the results of the model study of compressibility properties of fibrous, hemic and sapric peats stabilized with columns formed using the deep mixing method. Stabilized cement columns in the composite peat samples were prepared with cement:peat ratios of 50:50, 70:30, 80:20 and 90:10. The results obtained from the Rowe cell test were used for simulating the consolidation behaviour of peat with the help of PLAXIS 2D numerical software. It was observed that the effect of cement was higher on sapric peat than on others due to its cation exchange capacity, surface area and higher $\mathrm{pH}$. Compressibility parameters can be improved by increasing the column - area ratio in the stabilized peat and PLAXIS can be used to simulate the behaviour of peat in the Rowe cell. Roslan et al [2] used cement, bentonite, sand and calcium chloride for the stabilization of peat and they proved using the cone penetrometer test results that the bearing capacity of a stabilized column increased by $86 \%$ after its stabilization, due to the friction between the soil column and the surrounding soil. Bujang et al [1] compared the effect of lime and cement on the stabilization of peat. From the test results, they concluded that ordinary Portland cement (OPC) appears to perform better than hydrated lime due to quick pozzolanic reactions.

Sina et al [4] investigated the effectiveness of using different ratios of cement - sodium silicate system grout compounds with kaolinite on the mechanical and micro structural properties of peat after curing it for 3 and 30 days. The shear strength increased until the net charge of the sample changed to zero and thereafter it decreased with any further increase of calcium chloride because of the deflocculating of larger particles and the reverse trend in the moisture content. Behzad et al [6] analysed the effect of various curing techniques such as air curing, moist curing and moist curing with surcharge load adopted for the stabilization of peat with cement. The highest percentage increase in the Unconfined Compressive Strength (UCS) was obtained under moist curing with surcharge with a $50 \%$ of OPC addition. Wong et al [9] evaluated the strength characteristics of stabilized peat and found the economical mix in peat stabilization through laboratory tests. The results show that well graded siliceous sand largely contributed to gain early a higher strength as it enables cementation bonds at the contact points. Sodium chloride accelerated the rate of cement hydration in saturated peat there by increasing the initial strength. Ali et al [7] conducted a study to find the optimum amount of natural filler that will provide a higher shear strength using OPC as the binder. The optimum filler content for the higher compressive strength was found to be $125 \mathrm{~kg} / \mathrm{m}^{3}$ of well graded sand.

Prabakara et al [8] investigated the behaviour of soils mixed with fly ash in improving the load bearing capacity of soil. CBR value of the stabilized sample increased due to the interlocking phenomena of soil and fly ash. The specific gravity and the swelling index decreased with fly ash content while the cohesion increased. Kolay et al [10] found that UCS increases with the curing period after the peat has been stabilized with fly ash and gypsum separately. The optimum amounts of fly ash and gypsum that gave a higher UCS were $20 \%$ and $6 \%$ respectively. Kolay et al [3] investigated the changes in the compaction and UCS of peat soil with the addition of different amounts of Pond Ash (PA). The Optimum Moisture Content (OMC) decreases and the Maximum Dry Density (MDD) increases as the PA content of the mixture is increased, due to the consumption of pore water by PA to form cementitious products during the hydration 
process. UCS increases with PA addition which is due to flocculation and hydration process of PA. In addition, UCS increases as the curing period is increased.

However, to date, there have been no studies that focused on the stabilization behaviour of peat using ASTM Class F fly ash (low Ca) and well graded sand. Therefore, the major aim of this research study was to determine the geotechnical engineering properties of peat stabilized with a combination of low Ca fly ash and well graded sand. Ash containing $\mathrm{SiO}_{2}+$ $\mathrm{Al}_{2} \mathrm{O}_{3}+\mathrm{Fe}_{2} \mathrm{O}_{3}$ more than $70 \%$ by weight is classified as Class F, whereas those with $\mathrm{SiO}_{2}+$ $\mathrm{Al}_{2} \mathrm{O}_{3}+\mathrm{Fe}_{2} \mathrm{O}_{3}$ between $50 \%$ and $70 \%$ by weight is defined as Class C (ASTM 618). In this research, ASTM Class F fly ash obtained from the Norochcholai coal fired power plant was used as the main stabilizer. In Sri Lanka, annually 150 metric ton of fly ash is produced in the Norochcholai coal fired power plant and only about $20 \%$ of that quantity is used for cement production, thus resulting in a large amount of fly ash endings up in landfills. Therefore, it was decided to observe the improvements in the geotechnical engineering properties of peat after it has been stabilized using fly ash. Tests on Atterberg limits, standard Proctor compaction, unconfined compressive strength and Rowe cell were conducted as part of this research study.

\section{Materials and Methodology}

\subsection{Materials}

The materials used in this research were peat, fly ash and well graded sand. Disturbed peat samples were collected from Thorana, Kelaniya, Sri Lanka. This sample which was similar to slurry consisted mostly of roots, stones and larger particles. Fly ash was collected from Holcim Lanka Ltd, Puttalam, Sri Lanka. The composition of this fly ash is given in Table 1.

Table 1 - Composition of fly ash

\begin{tabular}{|c|c|}
\hline Constituents & Percentage (\%) \\
\hline $\mathrm{SiO}_{2}$ & 52.03 \\
\hline $\mathrm{Al}_{2} \mathrm{O}_{3}$ & 32.31 \\
\hline $\mathrm{Fe}_{2} \mathrm{O}_{3}$ & 7.04 \\
\hline $\mathrm{CaO}$ & 5.55 \\
\hline $\mathrm{MgO}$ & 1.30 \\
\hline $\mathrm{SO}_{3}$ & 0.07 \\
\hline $\mathrm{K}_{2} \mathrm{O}$ & 0.68 \\
\hline $\mathrm{Cl}$ & 1.00 \\
\hline
\end{tabular}

Well graded sand was obtained by performing the sieve analysis test for river sand collected from the premises of the University of Peradeniya. Well graded sand was prepared according to ASTM standard (D 2487-83) by adding a sufficient amount of particles of various sizes. The coefficient of uniformity $\left(C_{u}\right)$ of well graded sand is greater than 6, and its coefficient of curvature $\left(\mathrm{C}_{\mathrm{c}}\right)$ lies between 1 and 3 . Figure 1 shows the particle size distribution curve of well graded sand used in this research. It consists of particles from $75 \mu \mathrm{m}$ to $4.75 \mathrm{~mm}$. It was found that $C_{u}$ is 9.23 and $C_{c}$ is 1.16 for the well graded sand used.

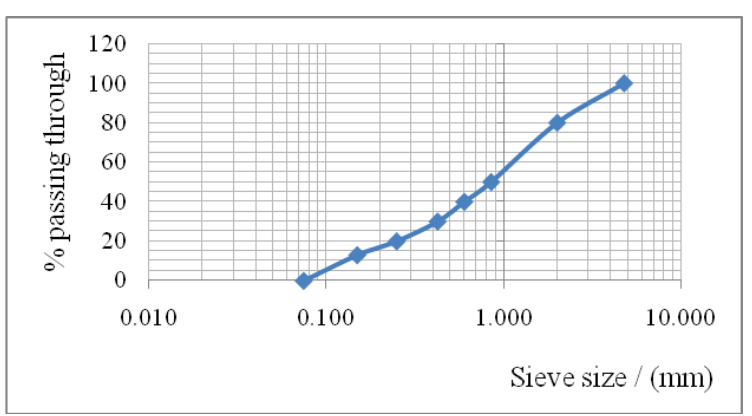

Figure 1- Particle size distribution curve of well graded sand

\subsection{Sample Preparation}

Firstly, the peat sample was sun dried for two weeks to facilitate sieving. However, due to the high water content that was present (natural water content $=101.9 \%$ ), it was difficult to make the sample fully dry even after two weeks of sun drying. Hence, the peat was oven dried at $105^{\circ} \mathrm{C}$ for two days and larger objects such as roots, stones, etc., were removed and the peat sample sieved through a $4.75 \mathrm{~mm}$ sieve to get a homogenously disturbed sample for further tests. Here, it was assumed that the organic matter present in the peat would not get lost when it was dried at $105{ }^{\circ} \mathrm{C}$, as the organic matter content determination involves oven drying of peat at $105{ }^{\circ} \mathrm{C}$ for 24 hours and then placing it for 5 hours in a muffle furnace operating at $450{ }^{\circ} \mathrm{C}$ [3]. Hence, it was assumed that there would not be any change in the organic content when the peat was oven dried at $105^{\circ} \mathrm{C}$ for two days. The quantity of well graded sand used in the mix was $125 \mathrm{~kg} / \mathrm{m}^{3}$ as it has been found that it is the optimum filler amount for obtaining improved geotechnical engineering properties [7]. Five types of samples were prepared with different amounts of fly ash $(0-30 \%)$ : (i) Raw Peat (P) ; (ii) Peat + Well Graded Sand (PSF0) ; (iii) Peat + Well Graded Sand + 10 \% Fly Ash (PSF10) ; (iv) Peat + Well Graded Sand + 20 \% Fly Ash (PSF20) ; 
and (v) Peat + Well Graded Sand + 30 \% Fly Ash (PSF30).

\subsection{Experimental Procedure}

Index Property tests such as Atterberg limits test (BS1377:Part 2:1990), Pyknometer test (BS1377:Part 2:1990) and Loss on Ignition test (BS1377:Part 3:1990) were conducted to find out bulk density, moisture content, specific gravity, liquid limit, plastic limit and organic content of the raw peat. The Standard Proctor Compaction test (BS 1377: Part 4:1990) was carried out to obtain the Optimum Moisture Content (OMC) and the Maximum Dry Density (MDD) of each type of sample. A mould with a diameter of 105 $\mathrm{mm}$ and a height of $115 \mathrm{~mm}$ was used and the sample was compacted in 3 layers through 27 blows applied using a $2.5 \mathrm{~kg}$ rammer at a dropping height of $300 \mathrm{~mm}$ per layer. Compaction curve was drawn by plotting the moisture content against the dry density. From the maximum point of the compaction curve, the maximum dry density and the optimum moisture content were obtained for each type of sample.

The Unconfined Compressive Strength (BS1377: Part 3:1990) test was conducted to find out the UCS of each type of sample for different curing periods (7 and 28 days). For the UCS test, a sample of $38 \mathrm{~mm}$ in diameter and $76 \mathrm{~mm}$ in height was prepared under optimum compaction conditions using compaction moulds and extruders. UCS apparatus with the loaded peat sample is shown in Figure 2.

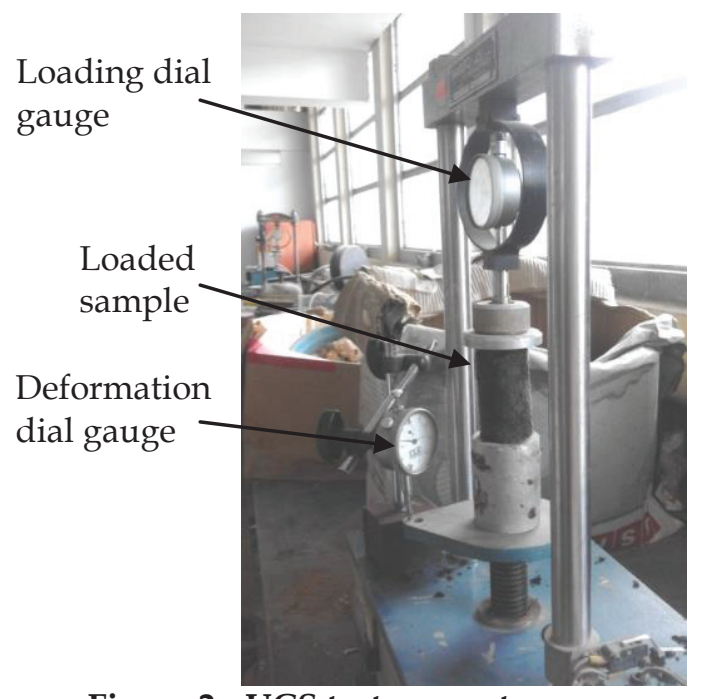

Figure 2 - UCS test apparatus

A constant strain controlled loading rate of 0.7 $\pm 0.1 \mathrm{~mm} / \mathrm{min}$ was maintained throughout each UCS test. For each data point, at least two samples were tested and the average of the results so obtained was taken as the value of the UCS. Rowe cell test (BS1377: Part 6:1990) was done on raw peat and on peat containing the optimum fly ash content and it gave higher values for the UCS.

In the Rowe cell test, consolidation pressures of 50, 100 and $200 \mathrm{kPa}$ were applied on the sample in order to find out its settlement behaviour over time. Throughout the test, an equal strain condition was maintained and one-way vertical drainage was allowed. A sample with a 151.8 $\mathrm{mm}$ diameter and a $50 \mathrm{~mm}$ depth was prepared with optimum moisture content and maximum dry density. Firstly, de-aired water was poured on the base and a porous plate was inserted. Thereafter, the sample was placed on the porous plate. After some de-aired water was poured on to the top surface of the sample, filter paper was laid on it. A diaphragm balloon was partially filled with water and positioned on top of the filter paper. All bolts and nuts were fixed simultaneously. The dial gauge was set vertically to read out the settlement of the sample. The diaphragm balloon was completely filled with water. The diaphragm pressure line, the drainage line and the pore pressure transducer were then connected to the Rowe cell apparatus. Figure 3 shows the connections to the Rowe cell apparatus.

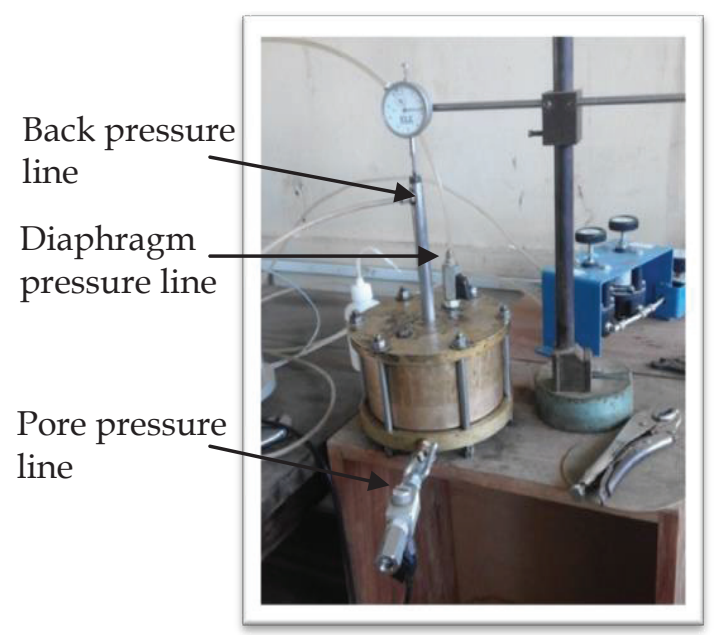

Figure 3 - Rowe cell apparatus

Initially, a $10 \mathrm{kPa}$ back pressure was applied continuously on the sample until the pore pressure reached a value of $10 \mathrm{kPa}$, to ensure the completion of the saturation. Thereafter, the drainage valve was closed and a $50 \mathrm{kPa}$ diaphragm pressure was applied. The dial gauge was set to zero after the pore pressure increased in value up to the applied diaphragm pressure. The drainage valve was then opened and the stop watch activated. The dial gauge reading and the pore pressure reading were taken at corresponding times. These procedures were repeated for the other two diaphragm pressure values (100 kPa and $200 \mathrm{kPa})$. 


\section{Results and discussion}

\subsection{Index Properties}

Table 2 shows the index properties of raw peat. Based on the results, peat can be classified as amorphous peat $[4,11]$.

Table 2 - Index properties of raw peat

\begin{tabular}{|l|c|}
\hline \multicolumn{1}{|c|}{ Properties } & Values \\
\hline Bulk density & $1055 \mathrm{~kg} / \mathrm{m}^{3}$ \\
\hline Moisture content & $101.9 \%$ \\
\hline Specific gravity & 1.90 \\
\hline Liquid limit & $101.2 \%$ \\
\hline Plastic limit & Non-Plastic \\
\hline Organic content & $83.7 \%$ \\
\hline
\end{tabular}

\subsection{Compaction Behaviour}

The variation of MDD and OMC of the different samples is shown in Figures 4 and 5 respectively. According to the Figures, peat with well graded sand and $20 \%$ of fly ash has the maximum MDD and minimum OMC. MDD increases due to flocculation when fly ash is added up to $20 \%$ by weight. As the flocs roll over easily on their own during the compaction process, peat-fly ash blends attain a higher density [13]. MDD decreases when fly ash content is increased beyond $20 \%$ because of the large quantity of water absorbed by un-reacted fly ash in the mix [14]. The optimum moisture content starts decreasing as fly ash is added up to $20 \%$ by weight. This is because the amount of water required would be less for the orientation of the particles when non-plastic and finer fly ash particles are added to the peat [15]. There is an increase in the OMC as fly ash content is further increased beyond $20 \%$ by weight since the water absorption of fly ash becomes high at higher moisture contents. Fly ash particles with dust like appearance have much more surface area to cover with water and hence the OMC will increase as more fly ash is added [14].

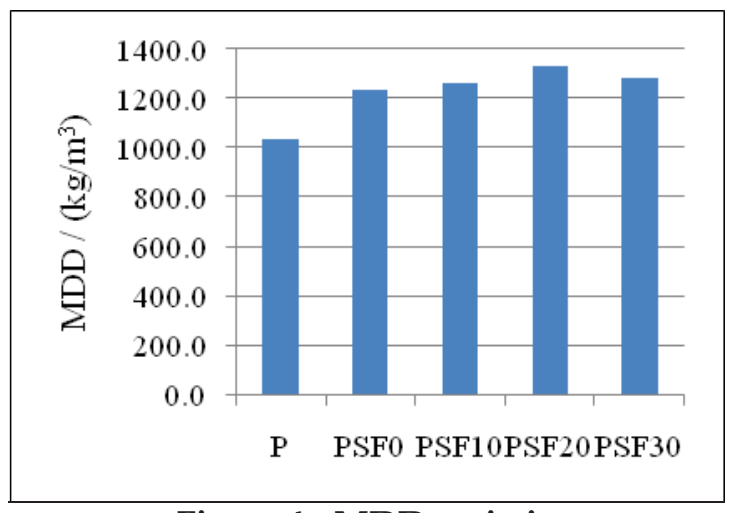

Figure 4 - MDD variation

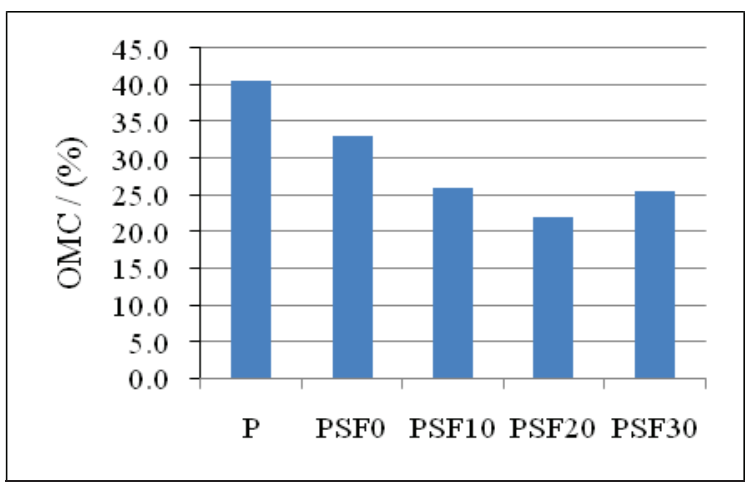

Figure 5 - OMC variation

\subsection{Uniaxial Compressive Strength (UCS) \\ Results}

UCS test was done for all five types of samples which were cured over three different curing periods. Figure 6 shows UCS variation with curing period for all types of samples. As can be seen from Figure 6, an increasing trend with the curing period can be observed in the UCS. This is because of the increased pore water consumption by fly ash from peat as time passes on during the curing period, to form cementing products during the hydration process [3]. Figure 7 shows the variation of UCS for each type of sample. There is an increase in UCS with the addition fly ash up to $10 \%$ by weight and beyond that value, UCS reduces as more fly ash is added to the mix. This initial increase is due to air voids in the peat were filled up with finer fly ash particles and the reduction is due to the un-reacted fly ash particles in the mix [3]. From these results, it is found that the optimum mix proportion of fly ash is $10 \%$ by weight and that this mix improves the compressibility behaviour of raw peat.

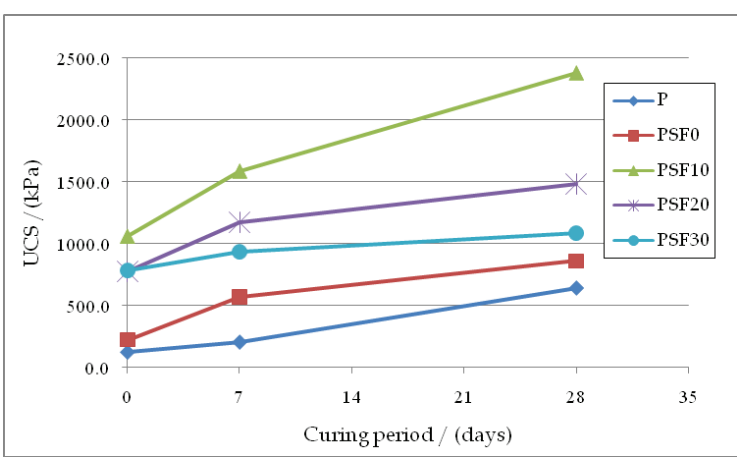

Figure 6 - UCS variation with curing period 


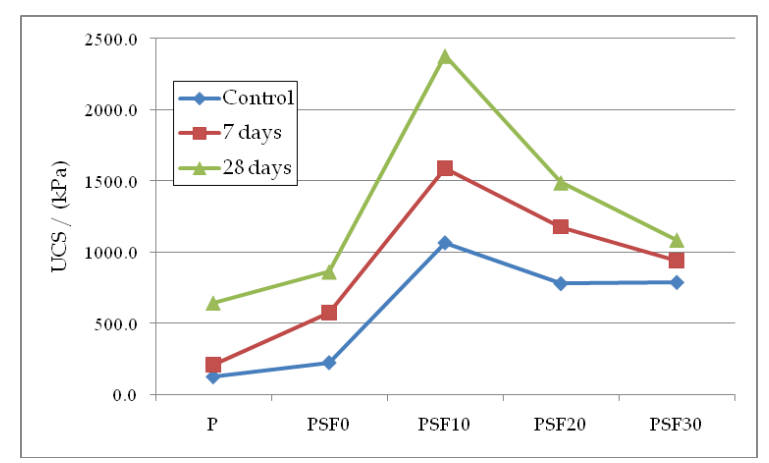

Figure 7- UCS variation with the type of sample

\subsection{Compressibility Behaviour of Stabilized Peat}

Rowe cell test was conducted on raw peat and peat stabilized with $10 \%$ of fly ash added (Composition giving the highest UCS). Figure 8 shows the variation of the settlement with time for raw peat and peat stabilized with $10 \%$ of fly ash. The percentage reductions in the settlement were $52.5 \%, 81.2 \%$ and $62.3 \%$ for 50,100 and $200 \mathrm{kPa}$ consolidation pressures respectively. Therefore, the settlement behaviour of the peat has improved after the stabilization. There is no secondary consolidation obtained for peat after adding $10 \%$ of fly ash. Figure 9 shows the void ratio variation with applied consolidation pressure for raw peat and for peat stabilized with $10 \%$ of fly ash. Using Figure 9, the compression index $\left(\mathrm{C}_{\mathrm{c}}\right)$ of raw peat was found. The values obtained are $C_{c}=0.548$ for raw peat and $C_{c}=0.149$ for peat stabilized with $10 \%$ of fly ash (Eq [1]). It clearly shows the improvement in the compressibility parameters after stabilization which is due to the flocculation of fly ash particles and soil particles [13].

$$
\mathrm{C}_{\mathrm{c}}=\left(\mathrm{e}_{2}-\mathrm{e}_{1}\right) / \log \left(\mathrm{p}_{2} / \mathrm{p}_{1}\right)
$$

Where $e_{1}$ and $e_{2}$ are initial and final void ratios respectively and $\mathrm{p}_{1}$ and $\mathrm{p}_{2}$ are initial and final stresses respectively.

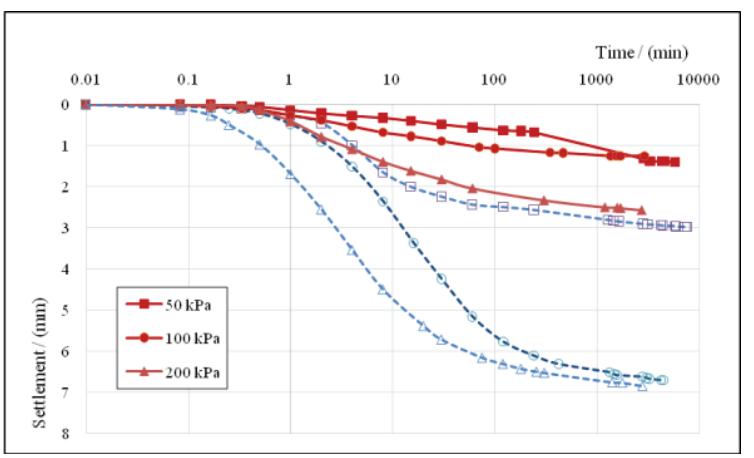

Figure 8 - Variation of settlement with time of raw peat (hollow line) and peat stabilized with $10 \%$ fly ash (solid line)

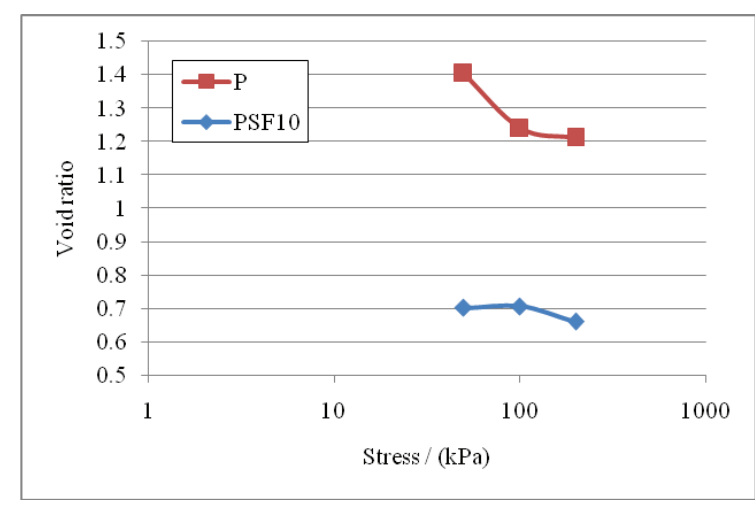

Figure 9 - Variation of void ratio with stress

\section{Conclusions}

An experimental study was conducted to study the geotechnical engineering properties of peat stabilized with well graded sand $\left(125 \mathrm{~kg} / \mathrm{m}^{3}\right)$ and with various amounts of fly ash $(0-30 \%$ by weight). The following conclusions could be drawn from the outcome of this study:

1. As fly ash is added to peat, the Maximum Dry Density (MDD) increases while the Optimum Moisture Content (OMC) decreases due to flocculation.

2. The optimum mix composition for a higher Unconfined Compressive Strength (UCS) is peat + well graded sand $\left(125 \mathrm{~kg} / \mathrm{m}^{3}\right)+10 \%$ ASTM Class F fly ash, caused by the filling up of air voids in peat with finer fly ash particles. Furthermore, the UCS increases with curing period due to the hydration process.

3. The outcomes of the Rowe cell test indicate that the settlement of $10 \%$ of fly ash + well graded sand $\left(125 \mathrm{~kg} / \mathrm{m}^{3}\right)$ is improved by $52 \%$ to $81 \%$ (depending on the consolidation pressure) as compared to raw peat.

4. On the whole, the findings of this research suggest that fly ash can be used as an effective stabilizer along with the well graded sand (10 $\%$ of fly ash + well graded sand) for the Dry Mixing Method (DMM) to improve peat lands.

\section{References}

1. Bujang, B. K. H., Shukri, M., \& Thamer, A. M., "Effect of Chemical Admixtures on the Engineering Properties of Tropical Peat Soils", American Journal of Applied Sciences 2., Vol. 7, 2005, pp. 1113-1120.

2. Roslan, H., \& Shahidul, I., "Properties of Stabilized Peat by Soil-Cement Column Method", Bund. J., Vol. 13, 2008. 
3. Kolay, P. K., Sii, H. Y., \& Taib, S. N. L., “Tropical Peat Soil Stabilization using Class F Pond Ash from Coal Fired Power Plant", International Journal of Civil and Environmental Engineering 3., Vol. 2, 2011, pp. 79-83.

4. Sina, K., Arun, P., Bujang, B. K. H., Jafar, B. B., Farah, N. A., Abdul, A., \& Mohammad, A., "Influence of Cement - Sodium Silicate Grout Admixed with Calcium Chloride and Kaolinite on Sapric Peat", Journal of Civil Engineering and Management., Vol. 17(3), 2011, pp. 309-318.

5. Bujang, B. K. H., Sina, K., Arun, P., \& Maassoumeh, B., "A Study of the Compressibility Behavior of Peat Stabilized by DMM: Lab Model and FE Analysis", Scientific Research and Essays., Vol. 6(1), 2011, pp. 196204.

6. Behzad, K., \& Arun, P., "A Study of the Effect of Various Curing Techniques on the Strength of Stabilized Peat", ELSEVIER Transportation Geotechnics., Vol. 1, 2014, pp. 119-128.

7. Ali, D., Kamarudin, A., \& Nazri, A., "Influence of Natural Fillers on Shear Strength of Cement Treated Peat", GRADEVINAR 65., Vol. 7, 2013, pp. 633-640.

8. Prabakara, J., Nitin, D., \& Morchhale, R. K., "Influence of Fly Ash on Strength Behavior of Typical Soils", Construction and Building Materials., Vol. 18, 2003, pp. 263-267.

9. Wong, L. S., Roslan, H., \& Faisal, H. A., "Behavior of Stabilized Peat Soils in Unconfined Compression Tests", American Journal of Engineering and Applied Sciences 1., Vol. 4, 2008, pp. 274-279.

10. Kolay, P. K., \& Pui, M. P., "Peat Stabilization using Gypsum and Fly Ash", UNIMAS EJournal of Civil Engineering., Vol. 1, 2010.

11. Youventharan, D., Bujang, B. K. H., \& Azlan, A. A., "Engineering Properties and Compressibility Behavior of Tropical Peat Soil", American Journal of Applied Sciences 4., Vol. 10, 2007, pp. 768-773.

12. Youventharan, D., Bujang, B. K. H., \& Azlan, A. A., "Methods of Utilizing Tropical Peat Land for Housing Scheme", American Journal of Environmental Sciences 3., Vol. 4, 2007, pp. 259264.

13. Phanikumar, B. R., "Effect of Lime and Fly Ash on Swell, Consolidation and Shear Strength Characteristics of Expansive Soils: A Comparative Study", Geomechanics and Geoengineering., Vol. 4(2), 2009, pp. 175-181.

14. Deng, F. L., Kae, L. L., \& Huan, L. L., "A Comparison between Sludge Ash and Fly Ash on the Improvement of Soft Soil", Journal of the Air and Waste Management Association, Vol. 57(1), 2007, pp. 59-64.

15. Suneel, M., Kwon, J., Jong, C. I., \& Chang, W. J., "Long Term Consolidation and Strength Behavior of Marine Clay Improved with Fly Ash", Marine Georesource and Geotechnology., Vol 28(2), 2010, pp. 105-114. 
